\title{
Resurrected Tradition and Revealed Truth: Dante's Statius
}

In Purgatorio 21-22, Dante leads into the climactic scene of recognition between Virgil and Statius, the first-century Roman poet, through a powerful allusion to the gospels, specifically to Luke 24 recounting the meeting of Christ after his resurrection with two disciples on their way to Emmaus outside Jerusalem. The analogy, drawn quite explicitly to Luke's text ("sì come ne scrive Luca"), pervades Dante's text down to its stylistic inflections. Luke's "Et ecce duo ex illis ibant ipsa die in castellum ... nomine Emmaus" echoes in the styleme - "Et ecco" - with which Dante's Statius is suddenly beheld:

Et ecco, sì come ne scrive Luca che Cristo apparve a' due ch'erano in via, già surto fuor de la sepulcral buca, ci apparve un'ombra, e dietro a noi venía....

[And behold, even as Luke writes that Christ, already risen from the grave, appeared to two who were on the way, a shade appeared to us, and came along behind.... ]

The "Et ecco" fixes attention upon the unexpected apparition to Dante and Virgil of the shade of Statius, catching up from behind on the way up the mountain of Purgatory, as something miraculous to relate, like the rising of Christ from the tomb ("surto fuor de la sepulcral buca"). The resurrectional thrust of the figure of Statius, the one soul witnessed actually rising up, "surto," to paradisiacal life in the Commedia, will be seen to transfigure the body of literary tradition that he symbolically carries with him. In his recreation of Statius Dante discovers and bears to the light of language the grounds in history of the transcendent truth of Christ; he shows this truth to be revealed through literature understood radically as poetic interpretation.

Beyond effects at the verbal surface, the far-reaching significance of the allusion for the meeting Dante arranges between Virgil and Statius turns on the initial non-recognition by the pilgrims to Emmaus of their Lord. Luke 24:15-16 reads: "And it came to pass, that, while they communed together, and reasoned, 
Jesus himself drew near, and went with them. But their eyes were holden that they should not know him." Statius' "ombra" similarly approaches Dante and Virgil incognito - he will in fact be asked who he is ("Ora chi fosti") only at line 79 - and they seem not even to notice him as he comes up from behind ("e dietro a noi venía"), so that the newly arriving shade must speak first ("né ci addemmo di lei, sì parlò pria"). Commentators go so far as to point out the analogy here with the Lukan model. Mandelbaum, for example, comments: "Two disciples of Jesus on their way to Emmaus, absorbed in thought and talk, did not realize that they were being accompanied by 'Christ, new-risen from his burial cave,' until He spoke to them" (369). However, it is actually not upon his speaking, nor even immediately in response to his expounding of Scripture, that the two disciples finally recognize Jesus. Only at a later moment is he known by them, precisely at the breaking of bread: "And it came to pass, as he sat at meat with them, he took bread, and blessed it, and brake, and gave to them. And their eyes were opened, and they knew him; and he vanished out of their sight" (24.30-31). The fact that recognition comes about in connection specifically with the action of breaking bread is emphasized once again when the two disciples report to the eleven back in Jerusalem what had transpired on their way, "and how he was known to them in breaking of bread" (24.35).

Luke's words are a verbatim rehearsal of the words spoken at the consacration of the Eucharist, of which the earliest written version, reflecting the primordial rite, appears to be that in I Corinthians 11.24: "he took bread, and when he had given thanks, he brake it, and said, Take, eat; this is my body, which is broken for you." As such they evoke a precise liturgical Sitz-im-Leben of the early (and perduring) Church in which Christ was recognized as present in the midst of his disciples in the celebration of the sacrament. Luke's understanding of what happened on the way to Emmaus is penetrated by this daily experience of the appearing, that is, of the flesh and blood presence, of the Lord to the faithful. This continuing experience shows up in Luke's text, at least when it is considered from a literary point of view, as reflected back into the sequence recapping the encounter on the road to Emmaus.

For Luke, it is in the life of the Church, nourished by the celebration of the sacrament, that the true identity of Jesus of Nazareth as the risen Lord is fully revealed. This event of true understanding is apprehended by Luke through an ongoing, living experience of Christ supervening upon him and his fellows "in the way." It is more exactly by its happening all over again in the present moment of the celebration of the eucharist that the apparition in the past along the road can be recognized as Christ, truly the one who was dead and is now alive. If it does not continue to happen in the present, the religious truth revealed in the past becomes opaque and reduces to reported facts, news items that can be reasoned over, but without direct experience and recognition of their manifest truth, any more than the pilgrims to Emmaus recognized the true identity of the Lord, whom they took to be a stranger. 
Luke's text indirectly demonstrates how the truth of Christ is revealed in the present experience of believers, each journeying along their personal way. For Christian truth must be lived. The recurring encounter with Christ sought by Luke and his community in the eucharistic rite, insofar as such ritual repetition coincides with the recognition of Jesus in the breaking of bread after some laying open of the Scriptures, just as in the Emmaus pericope, brings with it a crossfertilization with context that involves a principle of multiplication and dissemination of experiences of the miracle, the resurrected Christ. The event is not, or is not only or essentially, a self-identical object, an historical "fact," to be passively accepted "on faith," as the news, become dogma, is handed on from one generation of believers to another. On the contrary, the miraculous event is only apprehended by those who are within it participatively, recognizing Christ for themselves in his meeting with them personally, making them witnesses to his resurrection. ${ }^{1}$ And to this extent the event is always different, really new, and disseminatory.

Dante similarly emphasizes how Statius' recognition of the Christian truth latent in Virgil's text stems from his own personal experience in a world in which Christ is made present, is literally disseminated, in Christian worship and preaching (i.e. by "novi predicanti"):

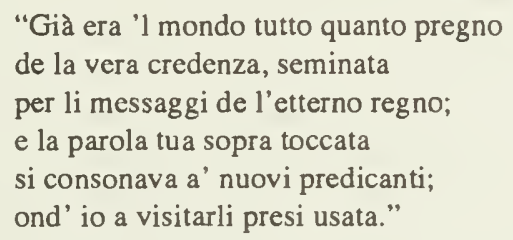

(Purg. 22.76-81)

["Already the world was completely impregnated with the true faith, sown through the messages of the eternal kingdom; and your word, touched on above, chimed with the new preachers; whence I took to visiting them."]

The word of Virgil "touched on above" ("la parola tua sopra toccata"), quoted by Statius a few lines earlier (70-72), is a passage from Virgil's 4th Eclogue (lines 5-7) hyperbolically celebrating the advent of a "new progeny" - most probably the birth of a son to Roman consul Gaius Asinius Pollio ${ }^{2}$ - as inaugurating a return of the Golden Age. By Christian interpreters, the passage was traditionally read, with blithe disregard for its author's own intention and context, or at least with inverisimilar assumptions in this regard, as a prophecy of the birth of Christ. And so Statius reads it too. But the way Statius describes his coming to this intelligence of the text lays decisive emphasis on the "consonance" between such a meaning and the gospel message sounding in the air around him and borne witness to by Christian lives ("i lor dritti costumi"), even to the point of their extinction in martyrdom ("quando Domizian li perse- 
guette").

Were it not for the contemporary experience of Christianity by which he is directly and personally touched, it seems safe to assume, adhering to Statius' own narrative logic, that the Christian prophetic meaning of Virgil's poetry, particularly of the 4th Eclogue, would have remained just as closed to him as it had been to Virgil himself. Statius is able to understand Virgil better than Virgil understood himself thanks to his own very different historical situation in an era of grace. The word of the gospel living and active within the Christian community and its preaching opens the way for Statius' Christian understanding of the pagan poet's text. The important point once again, as in Luke, is that the true meaning of a revelatory event or text is only one that can be lived and applied in the present, in the dimension of a happening of truth, for individuals actually engaged in understanding their own existence in its light. ${ }^{3}$

The way in which Statius' understanding of the truth of Virgil's poetry springs out of his own historically determinate situation has been highlighted by Dante, not only through the reference in $22.76-87$ to preaching and persecution under Domitian, but also in the exceptionally detailed, historically specific autobiography presented by Statius in Purgatorio 21.82-102 as preparation for the unveiling of his conversion in Canto 22. So far as can be determined on the basis of documentary evidence, Dante seems to have invented Statius' conversion, ${ }^{4}$ evidently in order to present his own experience of conversion, assisted by Virgilian poetry, in historically objectivized form. ${ }^{5}$ This works poetically in a way basically the same as the way in which the "history" (suspending the question of what history is) of an encounter along the road to Emmaus, whatever else it may do as history, objectifies in story form, as a discrete event, the faith experience of recognizing Christ in one's midst at the breaking of bread in the Mass. Just as in Luke it is the on-going experience of salvation in the Eucharist that makes possible, at least in the particular manner memorialized by the text, the recognition that the resurrected Lord had been accompanying the disciples all along the way, even in the darkest hour when they least suspected it, so it is Dante's own experience of being led towards salvation by Virgil's poetry that makes possible his recognition in Statius' life of a scenario of conversion coinciding with poetic biography.

Dante appears in effect to admit that his attribution of a Christian conversion to Statius lacks documentary historical foundation by inventing also a tradition of Statius' Christianity's having been kept secret ("ma per paura chiuso cristian fu'mi" - 22.90), which serves as an alibi for the unlikely circumstance that such a putative biographical fact should have remained unknown for so many centuries before being declared openly by Dante. This provides an additional hint of what is rather transparent in any case, that the life-story of Statius transfers to itself and objectifies what the whole Divine Comedy testifies was an overwhelmingly significant experience for Dante himself, namely his own encounter with Virgil's text as integral to his reception of Christian revelation and of a personal Christian-prophetic vocation. 
If Statius transforms the meaning of Virgil's text by understanding it in relation to his own situation and exigencies, then Dante does practically the same thing with Statius' biography, the text of tradition regarding the later Roman poet's life. Dante's self-consciousness about the hermeneutic process and its accommodation even of invention and manipulation of tradition in the unfolding of truth, that is, in the expression of the truth presently experienced in and through that tradition as resurrected and relived, is even more strident with respect to another Virgilian text interpreted by Statius, this time not the eclogue's prophecy of a new birth but rather a moral sentence in the Aeneid concerning greed or prodigality.

Virgil's text - "Quid non mortalia pectora cogis, / auri sacra fames?" (Aen. 3.56-57) - literally denounces the cursed hunger for gold, but Dante's Statius translates it as "sacra fame d'oro" and evidently understands the outburst as inveighing against the opposite vice, a lack of restraint in spending, that should be checked by sacred (not Latin sacer, blasphemous) hunger for gold. The meanings the phrase may have both in Virgil and for Statius are extremely controverted; the crux has provoked much pedantic scholarship, generally scandalized by the inaccuracy and exerting itself to find any conceivable justification for the apparently willful mistranslation of Virgil's lines. ${ }^{6}$ But what remains clear in any case, to us and to Dante alike, is that the meaning of the lines can shift radically relative to the situation in which they are understood. Statius' interpretation demonstrates how Virgil's text can be incorporated into his own life and, quite apart from considerations of philological "correctness" as the criterion of interpretation, disclose a life-giving, salvific meaning.

The important point made by the passage in this context representing Statius as numbered surprisingly among the redeemed is that Statius gathers a morally good and edifying meaning out of Virgil's text - one that saves him from being perpetually damned to the fourth circle of Hell ("sentirei le giostre grame" 22.42 ) - regardless of his philological probity or accuracy. Indeed the irrelevance of letter-correct philology in this context of understanding the moral meaning and saving truth of tradition gains a sharper point from the critical readings stressing the egregiousness of the error. Such letter-blind, but spiritually clairvoyant, "applied" reading was not lacking in august precedents. Augustine, in De doctrina cristiana (1.35-36), had proposed a similarly pragmatic exegetical criterion for determining legitimate meanings of Scripture based on whether or not they were conducive to engendering caritas ("ut huic aedificendi charitati sit utilis").

In this way, Dante explodes the illusory ideal of an objective meaning of a traditionary text to be ascertained by disinterested philological method, and rather probes the way in which the moral commitment and historical situation of the interpreter inform and make its meaning possible. Statius' understanding of the truth of Virgil's text is revealed as not a scientifically warrantable knowledge of a positively determined historical object but rather as itself a contingent, historically determined event. It is because of Statius' prodigality at the juncture in his personal history where he happens to encounter Virgil's text that the meaning 
of the text can be understood and taken to heart as an admonition against this excess. Thus the text occasions for him an event of moral enlightenment, exposing his sin and lighting the way to its correction; the truth comes out through this dynamic engagement with Statius' historically evolving existence, rather than by some sort of pure adherence to what Virgil in a remote past might be supposed to have meant. The meaning is disclosed as a function of what Statius lives in the present of his decision for moral conversion.

An analogous interpretive liberty must be taken, in turn, to discover the salvific sense of Statius' own poetry. Seen from a merely and disinterestedly historical point of view (that is, as something over and done with in the past), or in other words under the optics of the Muse of history, namely Cliò, Statius' works fail to make manifest any Christian meaning, as Virgil remarks:

"per quello che Cliò teco lì tasta, non par che ti facesse ancor fedele la fede, sanza qual ben far non basta."

["For by the notes which Cleo touches with you there, it does not appear that the faith yet made you faithful, without which good works do not suffice."]

Statius' answer, however, situating his outwardly pagan literary work in relation to his Christian life, hints that his oeuvre may have a hidden meaning. The account of his two-fold conversion experience (moral and Christian-prophetic) ends by pointing out an unsuspected allusion in his own work to a sacrament, namely baptism, recognizable as such, however, only retrospectively, in Dante's text where it is inserted into the silver poet's biography and into the general context of return to the innocence of the golden age:

"E pria ch' io conducessi i Greci a' fiumi

di Tebe poetando, ebb' io battesmo; ma per paura chiuso cristian fu'mi, lungamente mostrando paganesmo."

["And before I led the Greeks to the streams of

Thebes in poetry, I was baptized;

but out of fear I was a hidden Christian, a long time making show of paganism."]

Statius' leading the Greeks, by his pen, to the river, stated in conjunction with the disclosure that he himself had crossed the river of salvation through baptism, takes on the connotation of a possible Christian allegorical meaning buried in his 
own ostensibly pagan and historical poem. Does Statius' poem in this veiled manner figure a baptism of Gentiles? That indeed is precisely what his own story as an outwardly pagan but secretely Christian poet is about as Dante tells it. In any case, this hint represents an opening of the past and its true meaning to determination by interpretation in the present (and thereafter, by the same process, in the future) of a sort for which Dante makes Statius into a veritable emblem.

Dante had suggested in another way the openness of Statius' oeuvre to interpretation by calling attention to its incompleteness, when Statius says he died while the Achilleid was in progress ("in via" - 21.93). This leaves the final meaning of Statius' work, hidden to all merely historical knowledge concerning the mortal man, to emerge rather from the way Dante reads him, through his own faith; such is the hermeneutic condition of Statius' being recognized as one risen up from the river and baptized into the true faith. Once again a sacrament, this time not the eucharist but baptism, yet still a ritual manifestation and repetition of Christ's death and resurrection (cf. Romans $6.3 \mathrm{ff}$ ), serves as the enabling paradigm for Dante's retrospective reading of the true, which is to say the Christian, meaning of a pagan text, this time not Virgil's but Statius' own. It is Dante's reading of him in effect which baptizes Statius into Christianity, empowering this meaning buried in his life and works to be disclosed in truth, i.e. according to what had to be their ultimate truth for Dante.

That Statius' understanding and explication of Virgil's texts (like Dante's in turn of Statius' life and works) should be produced by their application to his own historical-existential situation, in such a way as to give those texts new and different meaning, traces out what has been recognized as normative for hermeneutic experience in general by Gadamer's contemporary "recovery" of the fundamental hermeneutic problematic. ${ }^{8}$ Under the heading of "Application" ("Anwendung"), taking a cue from Scriptural interpretation, Gadamer remarks that "the text, whether law or gospel, if it is to be understood properly - i.e. according to the claim it makes - must be understood at every moment, in every concrete situation, in a new and different way. Understanding here is always application" (309). The claim the text makes, according to Gadamer, is a claim to say something true, a point fundamental to the whole project of Truth and Method, as well as to the readings of Virgil by Statius and of Statius by Dante, both concerned quintessentially with truth, specifically with the truth of Christian revelation, as found reflected in these authors' texts. Needless to say, this is a truth which makes a claim, demanding conversion, in Dante's and Statius' cases, as a response. The way the truth in question exceeds all that any philological method or historical science can ascertain is vigorously thrown into relief by Dante's unflinchingly self-assured, albeit flagrantly unscientific, interpretations, vouched for only by his own poetic vision and religious witness.

Gadamer argues, in effect, that the historical situatedness of every act of understanding legitimates appropriations based on application to one's own present reality, for it shows this to be an inescapable, even if often covert, condition of 
any understanding at all coming about. It is thus that the very truth of Virgil's texts can be declared to be the Christian prophetic or moral one: not only does Statius happen to understand them within this perspective; the texts are not understood in their truth at all apart from some such existential application and appropriation. Somewhat disturbingly, however, the "different" understanding necessarily built into the hermeneutic process seems to bring with it no clear criteria for distinguishing between genuinely understanding and unscrupulously instrumentalizing a text. Dante seems to have underscored this eventuality by making Statius' interpretation, especially of the Aeneid text, as blatantly contradictory to the evident sense of the text as possible. Indeed objective criteria for "true" interpretation are in no wise forthcoming for Gadamer's unmethodological hermeneutics, any more than for Dante's grasping in faith the divine meaning of his seminal texts. In effect, such criteria are shown by Gadamer not to be possible, or at any rate not possibly certain, where the experience of truth in the interpretation of tradition is concerned. We have seen that Dante goes so far as to suggest that the disclosure of the profound truth of a text may be produced even by misprision. And yet, even so, as Dante represents it, this is not to throw interpretation open to the wanton and irresponsible arbitrium of purely subjective assertion and "impressionistic" reading. The interpretive liberties granted by Dante to Statius in the interest of the truth that is disclosed only in application are, on the contrary, displayed as being used responsibly; indeed they are deployed literally in response. Statius describes how he was reached by Virgil's poetry, already a centuries-old text, as if it had been spoken to him in conversation - "when you said" ("quando dicesti") — and as if Virgil had acted directly in person to re-orient the direction of his life: "You first sent me towards Parnassus ..." ("Tu prima m'in-viasti / verso Parnaso ..." - 22.64, 70).

Not an object, not even Truth in the abstract, the phenomenon experienced by Statius - the reality that comes over him - in his encounter with Virgil's text is that of being personally addressed: he is an ' $\mathrm{I}$ 'vis-à-vis a 'Thou'. This structure of personal address, so fundamental to the presentation of Dante's own poem to its reader, is highlighted through the personal pronoun used both with reference to and within the Virgilian text which alerts Statius to the error opposite to avarice, literally calling to him in his own existential situation with its specific risks:

\footnotetext{
"E se non fosse ch' io drizzai mia cura, quand' io intesi là dove $t u$ chiame, crucciato quasi a l'umana natura: 'Perché non reggi $t u$, o sacra fame de l'oro, l'appetito de' mortali?' voltando sentirei le giostre grame."
}

["And if it had not been that I set right my care, 
when I understood the passage where you call,

as if vexed with human nature:

'Why don't you rule, $O$ blessed hunger

for gold, the appetite of mortals?'

rolling I would feel the wretched jousts."]

The second "tu" by itself is an apostrophe of a common sort to an abstract entity, but it echoes a "tu," attributed to the poetic text or its author, explicitly calling with a voice of prophetic anger ("crucciato"), at least as it is understood by Statius in the event of understanding ("quand'io intesi"). The hearing of the address within the text is accompanied by a caring on the part of the ' $\mathrm{I}$ ' who hears ("drizzai mia cura"), hence in a dimension of concern that is perhaps equally a condition and a consequence of the enunciatory event of moral-prophetic address. Statius has to take a message addressed to humankind ("l'umana natura") in a particular way, applying it to his own life as addressed to him personally, for it to yield its truth to him.

In this way, paradoxically, the personal appropriation which makes a truth integral to Statius' own existence to be the point of a text already of distant provenance is what also enables the text to speak as a free and independent agency, a genuine otherness, that addresses Statius and claims him by the truth it announces. The event of appropriation which, superficially considered, seems to grant the interpreter a free hand actually appropriates him to what is being interpreted, pressing the interpreter's being into the service of responding to a call. The sequence shows how personal appropriation and even philologically indefensible applications of a text can be genuinely responsive to those texts and even honor their authority, perhaps more than (or alongside and together with) howsoever philologically painstaking and scientifically 'objective' an interpretation.

In Statius, Dante has compellingly illustrated how the truth of what is said (and even of what happens, as on the road to Emmaus) depends on the event of reading itself, that is, on interpretation/application, not only on what happened once upon a time. The exigencies of the reader together with the circumstances in which the event of reading takes place are not only built-in biases and barriers to understanding the original meaning; they are the conditions under which the experience of truth handed down in tradition can happen, if it happens at all. Naturally, conditions contemporary to interpretation of a traditionary text from the past may become impediments to understanding too, and so need to be checked or placed in abeyance, but this is secondary with respect to their necessary, constitutive role in the happening of any truth whatsoever, as the event of truth and its mediation by tradition is brought forth by Dante no less than by Gadamer.

The fact that Dante's poem is able to bring out a truth of history closed to previous ages, such as the conversion of Statius, or that Statius is able to interpret, retrospectively, the messianic meaning of Virgil's text, or again that Luke and other disciples can recognize Jesus as truly the resurrected one who accom- 
panied them all along the way, after the fact, in the celebration of the eucharist, opens to view a dimension of time as effectually intrinsic to truth. In each case, the truth remains sealed until interpretation, in a contextually specific way, brings it to the light of day in an event of disclosure. Truth, even when referred to and involving the past, always involves also a dimension of happening in the present. Dante was keenly aware of this, as we are perhaps in a position fully to appreciate once again today with the help of recent developments and recuperations in our theoretical understanding of interpretation.

\section{Historicity and Transcendence}

The particular historical circumstances in which Statius comes to understand Virgil's prophetic text - or the personal moral exigencies he brings to what he reads as a gnomic text - actually make possible the revelation in those texts of a truth that must remain extraneous to what was intended and understood in the same texts within Virgil's own historical context, even by Virgil himself. Dante accentuates at once the blindness of Virgil to the true meaning of his own text this is done indirectly by sounding the note of Virgil's eternal exile - and the truth which nevertheless he luminously conveys:

"Facesti come quei che va di notte, che porta il lume dietro e sé non giova, ma dopo sé fa le persone dotte...."

["You did as one who goes by night, who carries the light behind and benefits not himself, but after himself makes people wise...."]

The affirmation that Virgil was essential to Statius' finding of the faith - as paradoxical as this must be in a context where Virgil's own perdition is harped on determinedly and pathetically - brings Christian truth and tradition into intrinsic relation with its negation, with paganism, the tradition also of the "dei falsi e bugiardi." Dante pries into the event of conversion, his own as much as Statius', or again that of the "natura umana," and finds that it is inextricably bound up with and dependent upon an historical crossroads with what is ostensibly outside the plan of salvation. Faith is generated by what does not belong to faith but is kept without, consigned to eternal exile ("etterno essilio"), in the phrase from Virgil's own greeting of Statius:

... "Nel beato concilio

ti ponga in pace la verace corte

che me rilega ne l'etterno essilio." 


\section{[. . "May the true court which consigns me to eternal exile place you in peace in the blessed assembly."]}

The contrast between Virgil's horizon and Statius' own could not be more dramatic, as their divided fates serve to remind us. The fact that Statius comes to Christianity through Virgil, an historical circumstance of a blatantly improbable kind, constitutes a provocation and a reminder of the specific genesis of his understanding, its particular historical conditionedness, which cannot be erased or substituted for by some more evidently appropriate kind of occasion. The shining of a divine, absolute truth in human understanding is possible only on the condition that it be disclosed in partial, contingent, conditioned ways that bring to light understanding and its finitude together with truth and its universality.

This paradox shows how Dante in his treatment of Statius highlights the historicity of understanding. While it places emphasis initially on the limits imposed by historical conditionedness, Dante follows this ineluctable finitude of interpretation all the way to its extraordinary consequences: they include such possibilities as new, resurrected life of meaning and transcendent truth. For radical openness to the historicity of truth, paradoxically, brings with it radical openness to truth's transcendence of its own historical occasions. 'History' itself becomes relativized as a form of disclosure, i.e. as a determinate way of occurring of truth. This is perhaps the crucial insight the religious tradition Dante represents and realizes has to offer to a self-styled "post-metaphysical" modernity, clinging onesidedly to the revelation of historical relativity, while letting slip out of mind that by the same logic this too can only be relatively true, not substantially more correct than assertions of absolute truths. The submission to truth as an absolute which throws into relief how relative and contingent and fallible his or anyone's grasp of it is saves Dante from the absolute assertion that no such truth can exist.

The glaring irony of Virgil's exclusion from salvation, evoked insistently at just this juncture where Virgil is apotheosized as the prophet to whom Statius owes the salvation of his soul, for his having borne the light showing the way to Christ, demonstrates as starkly as possible the evident contradiction between history with its casualties and the transcendently saving meaning that literally rises up ("surge") from it. The skandalon of the resurrection, of the mortal body condemned to death, which nevertheless takes on new life as a glorious body, thus becomes the miraculous and enigmatic sign presiding over Dante's treatment of Christian truth and pagan tradition in the Statius cantos. The Resurrection is the symbol par excellence of historicity and transcendence affirmed together in their seeming contradictoriness. In the mystery of the resurrection, the body in its determinate, historical individuality is conceived as inextricably belonging to a life that is glorified and exalted, transcending the conditions of history, finitude, mortality.

Statius stands for the positive relationship between historicity and transcen- 
dence, between the extraneous occasion in pagan poetry and the revealed truth of religion reached thereby, that Dante interprets with such tenacity. Dante weds revealed truth indissolubly to the historical conditions under which it is realized, while at the same time transfiguring those very conditions so that they can be seen to belong to an order transcending nature and history, even to a plan preceding history. This conjunction of seeming opposites is built into Cantos 21 and 22 in all sorts of subordinate ways, resonating with the central thematics embodied in the paradox of resurrection, that is, of a finite, contingent body bearing eternal life, or analogously of a timely, chance occasion's being intrinsic to truth apprehended as eternal.

Statius' first discourse, a long exposition about how the mountain of Purgatory stands above the processes of nature causing perturbations in mundane existence -

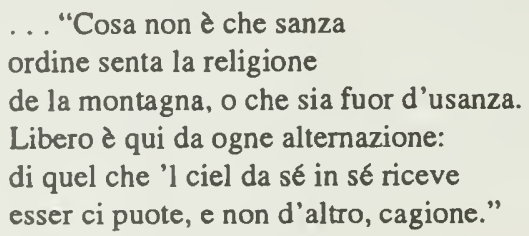

[ . . "The religion of the mountain suffers nothing that is without order or that departs from custom. This place is free from every change: that which heaven from itself into itself receives, and nothing else, can here be a cause."]

- explains that natural contingency is transcended in the realm of salvation above the three-step passage into Purgatory proper. This exclusion of contingency in the environment is the natural counterpart of the transcendence of contingency in history characterizing all who have been finally saved and culminating in the visions of Paradise, where history is contemplated as reflected in God, i.e. from the point at which all times are present (Par. 17.17-18), and where the distinction between substance and accident is annulled (Par. 33.88-90).

Although Statius' explanation affirms that contingency is transcended in the part of the mountain where they stand, this very explanation is called forth by a cataclysmic event leaving Dante and Virgil practically in a state of shock. Indeed above the threshold of Purgatory, shattering eruptions of earthquake and lightning seem to be integral to the life of the saved. The life of the spirit is itself an eruption as this canto and the poem generally present it. The difference obtaining on the side of salvation to which Dante goes over is that the suddenness of external events is an immediate manifestation of a divine rationale and fateful mean- 
ing.

That chance historical or biographical fact may be comprehended retrospectively as depending upon a providential plan determined by transcendent motives can now be understood to have been hinted at even in the description of the times of "good Titus," who in fact is mentioned as having avenged the Jews' killing of Christ by destroying Jerusalem with the help of God ("Nel tempo che 'l buon Tito, con l'aiuto / del sommo rege, vendicò le fóra / ond'uscì 'l sangue per Giuda venduto ..." [21.82-84]). Even such violent explosions of history in retrospect are transfigured as ordained by divine will. Similarly, Statius' migration from Toulouse to Rome ("tolosano, a sé mi trasse Roma") becomes a providential calling from a place far flung outside the circle of destiny to the cultural and spiritual capital of the Empire.

Nevertheless Dante refuses to forget, even after such transfigurations, the role of what could not but appear at the time to be casual circumstances as indispensable to the necessary happenings of true destiny. Statius' remark, for example, that he would have willingly postponed his assent to heaven for the chance to have lived in Virgil's time -

"E per esser vivuto di là quando visse Virgilio assentirei un sole più che non deggio al mio uscir di bando."

["And to have lived there when

Virgil lived, I would assent to a sun more than I owe before my release from banishment."]

- apparently breaks out of the teleological logic and hierarchy of values governing the story. It is incongruous that at this very moment of his emancipation from all worldly desire, purified for the desire of God alone, Statius should be tethered by such a human hankering (Cecchetti 106). This stray desire turning back towards earthly life, however, happens to be miraculously fulfilled in this very moment, as Statius is face to face with the poet he had so longed to meet. Chance here is transfigured as destiny. Such collapsing together of errant contingency with the significantly necessary is ciphered likewise in the smile that this very remark happens to bring to Dante's face. It provokes an observation that accident itself in bodily expression can be most revealing of truth:

ché riso e pianto son tanto seguaci

a la passion di che ciascun si spicca, che men seguon voler ne' più veraci.

[for laughter and weeping are so closely adherent 
to the passion from which each springs,

that they follow the will least in the most truthful.]

This smile, notwithstanding its spontaneous and inopportune quality (or even just because of this), is suffused with an eschatological light. The uncontrollable smiling shows up as a "lampeggiar di riso" (21.114), reflecting the lightning (or sunlight) that flashes in the face of Jesus transfigured on Mt. Tabor, as well as in those of the angels of apocalypse. The holy shout which is given up as the mountain quakes in celebration of Statius' soul's liberation -

"Tremaci quando alcuna anima monda sentesi, sí che surga o che si mova per salir sú; e tal grido seconda."

["It trembles here when any soul feels itself cleansed, so as to rise or set out to climb upward; and such a shout seconds."

- is likewise eschatological in derivation and finds its echo in the poetic apocalypse towards which the whole of Purgatorio crescendoes, prefiguring how the blessed shall rise wearing a new body and voice:

Quali i beati al novissimo bando surgeran presti ognun di sua caverna, la revestita voce alleluiando....

(Purg. 30.13-15)

[Just as the blessed at the new banns will rise ready, each from his cavern, the reclad voice singing allelulia .... ]

All the sudden, spontaneous gestures that are thematically highlighted in the canto, with its portrayal of the uncontainable emotions of Statius and of Dante, expressed respectively in a vain impulse to embrace Virgil and in the involuntary smile, are not merely natural phenomena happening by chance; they are here unveiled as playing a part in the fulfilment of a deeper scheme. In the final perspective of the poem, human and historical occasions are transfigured in a plan preordained from eternity. This paradoxical compenetration of superior fate and its chance occasion is expressed again another way in the syntax of Virgil's question, "qual sole o quai candele / ti stenebraron ... ?" (22.61-62), placing the divine source of all illumination, symbolized by the sun, alongside the apostolic bearers and disseminators of tradition in history, the candles, together in a parallel construction. ${ }^{9}$

Dante refuses to forget or elide the historical occasions of eternal salvation - 
Virgil being the chief exemplar of sparking salvation history while remaining unilluminated by it - and contemplates their utterly surprising coincidence with the work of providence, grace. The personal address that opened Christian revelation to Statius came unforgettably from Virgil. Dante cannot over-emphasize the importance for eternal salvation of this historical circumstance:

"Per te poeta fui, per te cristiano."

["By you I became poet, by you Christian."]

And in doing so he suggests, moreover, that conjunction of the necessary and the contingent in salvation is somehow intimately related to poetry.

What is the meaning of this deep-seated connection, this parallelism or virtual coinciding, between poetry and Christianity, in which the whole significance of the cantos about Statius is felt to be concentrated? Poetry constitutes the historical means by which Statius was led to the Christian truth which transcends history. Dante probes the interconnectedness and coincidence of the two. Virgil is expressly recognized as engendering Statius not only as poet but also as Christian. Virgil guides Statius in the art of poetry and also lights him the way to faith. But how to get from the one to the other? Between the two lies an abyss-like mystery. That a history without Christ, subject to all the chance perturbations that disturb nature below the gate of Purgatory proper, should nevertheless be the indispensible ground for revealing - and therefore also for discerning - the divine order of things is the ordinarily inscrutable riddle that Dante ponders in these cantos. Dante states, with confidence itself somewhat miraculous, the necessity to revelation of historical contingency and recalcitrance, the intrinsic relation to a condition which is always already loss, embodied monumentally in Virgil. The miraculous is that human life, historically conditioned as it inextricably is, should give rise to a transcendent meaning symbolized by the resurrection of the body. In accordance with this miracle, human life is claimed by the revelation of an eternal truth which Dante insists rises out of and is to be understood on the basis of the contingent character of human existence.

\section{'La divina fiamma'}

How, then, does Dante mediate this tension between the chance happenings of history and the significances of a divinely preordained destiny, or in other words the contradiction between historicity and transcendent truth, both of which are decisively affirmed here as throughout the Commedia? The answer the work gives and is, of course, is poetry. By understanding revelation of transcendent truth as inherently poetical so far as it touches us, on the one hand, and history as poetically made in a way involving but also possibly exceeding all human making, on the other, both historicity and transcendent truth can be understood to- 
gether as mutually implicated aspects of religious revelation. The inherent poeticality of religious truth, on the other hand, even when it is revealed as eternal or transcendent, emerges as the chief point and astonishing affirmation of the encounter with Statius as considered in these cantos.

At the very heart of the Statius saga lies poetry harboring the potential for transcendence towards a divine source. Statius says to Virgil:

..."Tu prima m'inviasti

verso Parnaso a ber ne le sue grotte

e prima apresso Dio m'alluminasti."

\section{[... "You first sent me towards Parnassus, to drink in its grottoes, and first, after God, enlightened me."]}

From Parnassus to God; the one follows hard upon the other. This is the same sublime sequencing as operates in "Per te poeta fui, per te Cristiano" (22.73). Poetry conducts in this last passage, via the thin stroke of a comma splice, from the human to the divine.

The continuity and even the coinciding of the human and the divine, as in the Incarnation, Dante understands to be humanly attainable essentially in and by poetry. In fact Statius the poet, in essence a Christian Virgil, is Dante's most overt figura Cristi. ${ }^{10}$ In Statius, Dante realizes the peculiar vocation of poetry to raise (marked by the "surto" language for both Statius and Christ) humans to the level of the divine, to bestow on human activity and making an immortal dimension of significance. Poetry's potential proximity to the divine, to which it offers humans a sort of access, was promoted in the ancient cult of poetry, signally by none other than Statius himself, for example in the envoi addressed by the poet to his own work at the end of the Thebaid, with its homage to the "divine Aeneid" of Virgil: "Vive, precor; nec tu divinam Aeneida tempta, / sed longe sequere et vestigia semper adora" (12.816-17). This tribute echoes in the words with which Dante's Statius celebrates the Aeneid, repeating the same word "divina" in conjunction with a metaphor that we have already seen is applied also to the saving word of the gospel message, that of the "seme" (seed);

\footnotetext{
"Al mio ardor fuor seme le faville, che mi scaldar, de la divina fiamma onde sono allumati più di mille; de l'Eneïda dico, la qual mamma fummi, e fummi nutrice, poetando: sanz'essa non fermai peso di dramma."
} 

["Seeds of my ardor were the sparks, which warmed me, of the divine flame by which more than a thousand are illumined; of the Aeneid, I say, which a mother was to me, and to me was nursemaid in making poetry: without it I would not have been worth a drachm."]

Poetry as a sacred flame ("divina fiamma"), as a seed ("seme") of salvation or divine spark ("favilla"), as mother providing vital nourishment (made phonetically palpable in the infantile "mm" humming doubled and thrice-resounded through the second terzina), becomes the living link between the human and the divine, the historical and the transcendent. While Virgil's poetry becomes natural mother to Statius, the natural here is continuous with the spiritual, like the "sete natural" of the Samaritan woman, alluded to along with the Emmaus pilgrims at the beginning of the whole sequence, satiated by "grazia" (21.1-3). In poetry, that is, in "making," it is possible to discern the human as divine, nature as grace.

Fleshed out in these as well as in other ways, "Per te poeta fui, per te cristiano" runs together the path to poetry with that leading to revealed Christian truth. Is this convergence just Statius' own personal case or, behind this, just Dante's peculiar experience? Granted, one need not become a poet like the two of them in order to embrace the faith. Yet their life-story, in its context in Dante's poem revealing the nature of Christian experience of truth in general, takes on emblematic significance. It is, to be sure, presented as belonging to an individual lifehistory, but it is also representative of something essential in the relations between poetry and revelation. As we have seen, with reference first to the experience of the pilgrims to Emmaus, religious truth is revealed within a participatory act (such as ritual repetition in the eucharist), a consenting which is also a making and a making possible, a voluntary or free movement of faith which is at the same time understood as given by grace.

This means that communication and memorialization of religious experience is itself inherently poetic, and consequently religious revelation is itself a "making" which involves human spontaneity and creativity embraced within the event of divine self-disclosure. Luke notes that the resurrected Lord might have passed the disciples by on the way to Emmaus, but something within them, a disposition rendering possible the experience they are to have, makes them wish to detain him: "And they drew nigh unto the village, whither they went: and he made as though he would have gone farther. But they constrained him, saying, Abide with us . . ." (24.28-29). Once again, after Jesus had been revealed to them, and then had immediately vanished out of their sight, "they said to one another, Did not our heart burn within us, while he talked with us by the way, and while he opened to us the scriptures?" (24.32)

This burning heart, as interior correlate to the presence of the Lord and his opening of prophetic tradition, registers something essential about the locus of 
the event of truth. While it is localized in external space, i.e. in the real presence of the Lord in their midst along the way to Emmaus, this putatively objective phenomenon is perceived in its true identity only by a burning heart and a soul so disposed that it bids the stranger to stay. The heart so burning functions as a metonymy for faith as the condition of religious understanding. In some sense, faith "makes" its object, even while understanding itself as being induced by a higher Maker; as in all poetry, something objective is made which helps communicate an experience of what is not properly objectifiable at all.

Here we touch upon the poetic making at the heart of religious experience. There is always something obscure in the miraculous, in Christ's surging up from the "sepulcral buca," in his suddenly being seen ("Ecco," behold) with the pilgrims to Emmaus, in Statius' coming up from behind, overtaking Virgil and Dante. The Resurrection itself is never witnessed; there is no account in the gospels of the event's actually transpiring, but only of the disciples' experiences, after the fact, of their resurrected Lord. The mystery is always reached through interpretation directed backwards to what is unknowable in itself and can be spoken of at all only in terms of the interpretative experiences arising from it. The compenetration of these natural experiences of making and the mystery/miracle that animates and transfigures them gives the human acts the character of something miraculous in their own right. Dante suggests later, when examined on faith, that even if there had been no miracles such as the Bible attests, the fact of the faith's universal spread would be miracle enough to prove its veracity:

"Se 'l mondo si rivolse al cristianesmo"

diss' io "sanza miracoli, quest'uno

è tal, che li altri non sono il centesmo."

(Par. 24.106-08)

["If the world converted to Christianity"

I said "without miracles, this one alone

is such, that the others are not one-hundredth of it."]

This argument is obviously specious from a logical standpoint, but is quite accurate as a description of an aspect of the effectual working of revelation in history, by virtue of its clairvoyance concerning the miracle potentially transpiring in interpretation itself.

What is obscure in religious experience is that which resists objectification, that which does not belong to the order of objective experience at all, the supernatural and otherworldly. And yet religious experience and witness, since time immemorial, has continually sought objectifications to serve its need for self-expression. In doing so, it has operated poetically. The human making which makes communicable the experience of what transcends representation belongs intrinsically to religious experience, and it comes to be played out to its fullest extent, reaching a plenum of expression, in the religious poem of Dante. Dante makes 
the poetically objectified other world of religious experience the very "argument" of his work.

\section{'Secol si rinova'}

The world as new and other, precisely the "other world" as Dante presents it, or in other words a world transcending what we know as the world and what comes to pass in recorded history, is the perennial theme of poetry that comes to climactic expression in the Virgilian prophecy cited by Dante as divinely inspired. What Dante has divined to be the message at the core of poetry, distilled into the "divine" verses of the Aeneid which for him summed up the meaning of all ancient poetry, is precisely the proclamation of the renewal of the world, of the advent of a new progeny, of the universe set right again:

... "Secol si rinova;

torna giustizia e primo tempo umano

e progenie scende da ciel nova."

(Purg. 22.70-72)

[. . . "The world grows new again;

justice returns and the first human age, and a new progeny descends from heaven."]

We can begin to understand poetry in accordance with its hermeneutic meaning, its fundamentally interpretive character as "making," by following this hint about its essential content. Poetry represents the world as new. Its central message is that of the dawn of a new age, for by its representations, with their distance from the actual world, it prepares the way for a happening of the world as new. Our relation to the world — and thereby the world itself — is made different through poetry. This sense widely shared among poets finds a theoretical exfoliation in Gadamer's theory of hermeneutic experience as essentially experience of the new, or rather as any experience whatever being experienced as new: "The nature of experience is conceived in terms of something that surpasses it . . . The truth of experience always implies an orientation toward new experience. That is why a person who is called experienced has become so not only through experiences but is also open to new experiences" (Truth and Method 355). ${ }^{11}$

This openness to the new, at the same time a return to the old, is the defining characteristic of hermeneutic experience as Gadamer describes it, essentially the experience of tradition as new. Not itself any specific experience, hermeneutic experience depends on the capacity to receive new experience, which means also to experience as new all that has been traditionally experienced, as at once other and one's own, and as the opening of a horizon upon one's unknown future.

In its projection of a new world, or of the world as new, the structure of hermeneutic experience so construed coincides with the vital substance of poetry as 
Dante understood it. Dante repeatedly reverts to poetry's sovereign myth, that of the renewal of the Golden Age ("secol si rinova"). This mythic reign of natural justice under Saturn, as it was dreamt by the ancient poets, is identified in the Edenic paradise at the apex of the Purgatorio as an obscure version of the original place of innocence in the Biblical account of the Garden of Eden:

"Quelli ch'anticamente poetaro

l'età dell'oro e suo stato felice

forse in Parnaso esto loco sognaro."

(Purg. 28.141)

["Those who of old sang

the age of gold and its happy state

perhaps with their Parnasus dreamed of this place."]

Similarly, the Statius sequence itself in cantos 21 and 22 concludes with an allusion to the first age, figured by the poets as good as gold ("Lo secol primo quant'oro fu bello"), taken as adumbrating the New Testament age inaugurated by the return to nature of John the Baptist. John, who ate locusts and wild honey, ushers in the new dispensation with a natural simplicity prefigured by the nuts and nectar of the fabled golden age, projected by the poets into an idealized past but openly revealed in the gospel: ". . . quanto per lo Vangelio v'è aperto" 22.148-54.

The world is new to the extent that it is in and through poiesis. For it is the "making" which in poetry is constantly in emergence that makes the world and makes worlds possible for human experience. Dante captures this essential creativity, this world-renewing power of poetry both in linking it with religious renewal, that is, with Christian redemption of the world and of the individual soul in the resurrected life, and in highlighting the classic Golden Age myth, coinciding with the Edenic "truth" of Scripture, as the quintessential argument of poetic tradition.

Dante's whole journey through Purgatorio is structured as a return to the origin of human existence, to the Garden of Eden as well as to the state of original justice that Man enjoyed there. It throws into epic relief the historical nature of understanding in unveiling the advent of the new as the return of the old. Whatever is presented to us is understood in terms of these coordinates. Understanding is intrinsically a recapitulation of the past and at the same time an openness to the new. Only by this structure is recognition possible on the one hand and receptivity on the other - which together may be taken as the essential component functions of understanding, its double sine qua non, even of the understanding of revealed religious truth.

The itinerary of Dante's poem could hardly make it clearer that the return to the golden age that existed before historical time is possible only in time, through history, and specifically through history understood as poiesis. Dante has to work 
his way through Hell and Purgatory (and so also through Inferno and Purgatorio), through both "temporal fire and eternal," assuming the whole burden of history with all its entrapments, in order to arrive at the Garden. Salvation entails not simply being lifted out of time into eternity but rather a process of purgation working through time, where grace can reach us and bear us "all'eterno dal tempo."

In thus resurrecting the tradition of a Golden Age that was so central a myth for pagan poetry, and in proceeding to interpret the originary identity of this resurrected tradition with the revealed truth of the biblical Garden of Eden, the Purgatorio, pivoting on the Statius encounter, throws into relief a correspondence and indeed coincidence between the interpretive resurrection of tradition and the revelation of transcendent truth. The Emmaus pericope itself, we saw, is contrived so as to suggest how the real presence of Christ is revealed in the reliving of experiences preserved in tradition; there revealed truth in the strict sense of Scripture shows itself as resurrected tradition. Dante's insisting on how even pagan tradition, when given new life through Christian interpretation, can be understood to lead to revealed truth underscores yet more conspicuously how revelation works precisely through the resurrection of tradition achieved in and by hermeneusis.

\section{Art and Immortality}

Gadamer's philosophical hermeneutics, for all its emphasis on the finite historical conditionedness of understanding, also aims to render intelligible such a "suprahistorical value" ("übergeschichtlichen Wert") as "the classical" (Truth and Method 287). Hermeneutic consciousness and self-reflection makes possible a rehabilitation of this concept, from being a term merely descriptive of an historical period and style, to the normative status that belongs to it in the hermeneutic experience of truth. In this sense, the "classical" work of art serves as a touchstone of values such as beauty and truth, prescinded from mere fluctuating standards of taste. A normative concept deserving to be called "classical" is transhistorical because it is always already operative before historical reflection begins; it is a constitutive, structuring part of the tradition within which alone such reflection can be carried out. The classic, before it begins to be consciously examined, becoming an object, always already shapes reflection on aesthetic values through the binding power and authoritativeness of the standards it embodies.

The classical is defined by Gadamer, following and adapting Hegel, as "selfsignificant" and "self-interpretive." By this power of interpreting itself, the classical reaches into the present and addresses it; thus the classical precedes, encompasses and anticipates later-day interpretations within its own already-in-progress self-interpretation: "the classical preserves itself precisely because it is significant in itself and interprets itself; i.e. it speaks in such a way that it is not a statement about what is past - documentary evidence that still needs to be interpreted - 
rather, it says something to the present as if it were said specifically to it" (290). This suggests specifically how the hermeneutic theory of the classic finds in the instance of the Commedia as classic, with its highlighting of the address to the interpreter, an exceptionally acute and self-conscious instantiation.

Moreover, Dante himself has woven an ideal of the poetic classic as resistant to time together with his model of Christian salvation and resurrected life in the Statius cantos. Statius' remark that "poet" is the name that most endures and honors ("il nome che più dura e che più onora" - 21.85) gestures towards a trans-historical value in literature parallel to the eternal truth of the word of the gospel. The parallelism achieves lapidary form in the line in which Statius gives credit for his discovery of enduring, preserving, saving value in both the literary and the religious domains at once to that greatest of classics, in Dante's view, Virgil: "Per te poeta fui, per te cristiano" ("Through you I became poet, through you Christian.")

Purgatorio 21-22 intimates that poiesis is fundamentally a way through which humans may participate in immortality. Though immortality is certainly a gift from the transcendent Lord of life, it does not come as an object wrapped up neatly for humans in a package. It comes, or rather is given, through their own making, through an active involvement with what transforms them in self-transcendence. Taken in its etymological sense of "making," employed by Dante in De vulgari eloquentia 2.4 , poetry can encompass the nature of all art, and it is in this sense also that art becomes so fundamental to the experience of all of Purgatory, issuing in the rising up to an eternal life.

Art and quintessentially poetry is how humanity participates in creating enduring forms. To the extent human beings aspire to what they interpret as some eternal form of existence, the nature of interpretation dictates that it can be attained only by participating in its making. All of the Purgatorio illustrates how human effort contributes to the work of redemption through purifying and edifying. Salvation does not merely fall out of the sky. Its unconditional transcendence of all human possibilities must, on the contrary, be received, nurtured and "seconded" (see Virgil's discourse on love: Purg. $17.82 \mathrm{ff}$ ) within the human sphere. The integrity of the secular order in coordination with the divine dispensation is well recognized as one of the determinative constants in the work of Dante as "poet of the secular world." Hence also the argument with regard to human freedom - and its need to be guided and disciplined - in Purgatorio $16.73 \mathrm{ff}$, so central thematically as well as numerically to the cantica. This freedom is exercised eminently in the art of poetry, where self-fashioning through interpretation opens possibilities for freedom vis-à-vis one's whole world of experience.

The Purgatorio teaches that a genuine participation in divine reality is fashioned over time by assiduous human effort, and poetry is exalted as the model for this human endeavor of self-fashioning in the divine image. This is the great message particularly of the Statius cantos, as Giovanni Cecchetti has so well ap- 
preciated. In the symbol of Statius, a poet in the genealogical line by which Dante defines his highest conception of poetry, "poetry becomes the means for guiding humanity on the road to salvation and immortality in the broadest and deepest sense" (96).

Because salvation is realized through a making which transpires essentially in time - and all the images of action and endurance of souls in Purgatory depict this temporal dimension of sanctification - there is also inevitably loss. Time at least in human experience as we know it - even while serving as the medium of redemption and reformation, at the same time distances and deletes, and Dante agonizes over its losses. Virgil, in the economy of the Commedia as a whole, tragically symbolizes this concomitant loss inherent in the temporal nature of existence.

In the person of Statius, by contrast, the discipline of poetry (not to the exclusion, naturally, of penance) is manifestly fused into the efforts by which the soul frees itself from Purgatory and the struggles of time into eternity. Of course, the delusion of achieving immortality through poetry or through any other human endeavor has also been acutely exposed and damned in several of the most outstanding episodes of the poem. Brunetto Latini's teaching how man eternalizes himself ("come l'uom s'eterna") through humanistic works such as his Tesoro is seen to have blown up in his eternally charcoled face. Similarly, the prologue scene, especially as Freccero teaches that it be read, would demonstrate the futility of all efforts to attain, by the power of human intellect, i.e. neoplatonically, the redeemed state symbolized by the top of Mount Purgatory; rather, the pilgrim has to go down into Hell along the other way ("altro viaggio"), that of conversion, completely surrendering all his human resources in unconditional abandonment to the divine. Ulysses, sailing by the guidance exclusively of human virtue and knowledge, "virtute e canoscenza," with all his stirring rhetoric, belongs to the same constellation a false star-seekers.

Yet all these powerful scenes are not strong enough to discourage Dante from entrusting to an irreducibly poetic itinerary his own journey to salvation. Centrally in the Statius episode, together with the concentration on poetry thenceforward to the end of the Purgatorio, Dante emphasizes rather the continuum between the human activity of "making" and the divine. ${ }^{12}$ In this conjunction, Dante shows himself willing to embrace the ancient pagan cult of poetry and poet ("il nome che più dura e più onora") as attaining to immortality, sublating the ancient immortality of fame into the eternal life of Christian resurrection. Although he has shown poetry and its meaning and truth to be historically determined in absolutely decisive ways, still he also sees it as leading beyond the temporal order, "a l'etterno dal tempo."

This opening upon something infinite and immortal opens precisely in the historical situatedness which characterizes so quintessentially the act and event of poetry. Dante's exaltation of poetry as a way of communicating with divinity and as a vehicle to immortality is no mere reiteration of the idealizing clichés and 
self-deceptions he himself devastatingly critiques. Rather, in the phenomenon of poetry he is contemplating the central mystery of the Christian religion, the mystery of the Incarnation (of which the Resurrection, through its affirmation of the necessarily and eternally incorporated nature of human life, is a corollary), the mystery, that is, of a transcendent God existing as an historical man, in order to make it possible for humans again to share in the divine life. The making and interpreting which poetry essentially is constitutes a nexus between the human and the divine.

This connection becomes conceivable only when we learn to view poetry as interpretation and to understand interpretation hermeneutically as an event involving humanity ultimately with its other, with what utterly transcends it, namely divinity. Poetry of the sublime sort treated here by Dante is not essentially only a human activity - although unmistakably it takes up and includes the human, even as condemned, as in Virgil - so much as a participation in an event of the divine. This stupendous possibility is developed by Dante in the episodes involving poetry in the Purgatorio following in the wake of the Statius cantos, signally where he describes himself as one who writes poetry by taking dictation interiorly from an inspiring Love ("quando / Amor mi spira, noto" 24.52-53). Poetry's potential for vehiculating transcendence towards a specifically Christian divinity is implied in the Trinitarian underpinnings of the poetics Dante adumbrates in these famous verses defining his "dolce stil novo." 13

The openness of human, historical existence to historically transcendent value, as in the classic as theorized by Gadamer, has been understood throughout literary and philosophical tradition in terms of the phenomenon of poiesis. It is the nature of poiesis to be open to transcendence. The making involved in poetry involves the agent in an event that transcends conscious control and the boundaries of the activity of an ego, making that very agent into something other, transcending the self in the relation to what transcends it. This aspect of the ontology of "making" in art has been explored by Gadamer particularly under the rubric of "play." The game involves its players in the happening of an event that reaches beyond them, remaking them and bestowing on them an augmented being.

The faculty of poetic making is what brings out in human beings their status as not simply being within the world but as able to transcend it in making a new and different world. (In so doing, of course, they also transcend themselves, so that the doing is no longer "theirs" in any simple, static sense.) For the activity of making brings into evidence the transcendental coordinates which determine everything within the world. Human making is never itself an object, or never merely such; even the objects it produces bring into play and into question the coordinates in terms of which objects can be determined. Human making or poetry in this sense concerns what transcends all that is within the world. The world itself in the making of poiesis, therefore, is necessarily presented as "new." Poetry as interpretive making is the human act by which the world is discovered in its newness as what asks to be characterized, by virtue of its unworldly, extra- 
worldly nature, as a divinity-revealing event.

In this regard, it is worth looking more closely at how poetry becomes the specific pre-occupation of the cantos immediately ensuing upon the Statius sequence and, in a more general manner, the pervasive theme of the second cantica as a whole, punctuated as it is by the meetings with Dante's poetic progenitors, beginning from its opening scenes with Casella and then Sordello. The cantos following 21 and 22 in the Purgatorio, including Dante's encounters with nearly contemporary and earlier poets (Forese Donati, Bonagiunta da Lucca, Guido Guinizzelli, Arnaut Daniel), further develop the eloquent hint given in 21-22 as to poetry's being a theological hermeneutic or vehicle of the divine Word.

The meeting with Forese among the penitent gluttons serves to revise and redeem Dante's scarcely edifying exchange of insults, in the form of a scathing tenzone, with this poet and relative. Therewith it participates in the general purification of poetry underway throughout the Purgatorio. Dante first hears "Labia mea, Domine" from the midst of the gluttonous, whose prayer for purification centers on the external organ for speaking, the lips. In addition to exemplifying poetry in the form of liturgy - and therefore of participation in divinity and in making Godlike, an integral feature of Purgatory at every ascending stage - this quotation from Psalm 50 is apt to suggest how Dante's own lyric poetics can be seen in the end to converge upon sacred poetry. For the complete verset of the Vulgate which this incipit invokes ("Labia mea, Domine, aperies; et os meum anuntiabit laudem tuam") alludes to the poetry of praise that was discovered by Dante as the keynote for his dolce stil novo. ${ }^{14}$ In this praise-style, Dante finds for his poetry "materia nuova e più nobile de la passata" ("new and more noble matter than that of the past" [Vita nuova 17$]) .^{15}$

In Canto 27, Dante crosses into the earthly paradise, where nature and grace coalesce and where art is effortless and redeemed. Here, in the "divina foresta" (28.2), nature in fact is divinized through art, as in the song of the birds, which has become a natural liturgy ("con piena letizia l'ore prime, / cantando" 28.1418). Here Dante is regaled with the high artifice of an allegorical vision representing individually, with poetic fancy, the very books of the Biblical revelation (Canto 29). Poetic allegory, moreover, comes to be employed expressly as the medium of divine prophecy in the visions which Dante is commisioned to write down "in pro del mondo" ("on the world's behalf") in the concluding cantos (32.103-05, $33.52 \mathrm{ff}$.).

The theme of poetic representation as veiled theological revelation builds to a climax in the symbol of Beatrice, entering dramatically, "velato sotto l'angelica festa" ("veiled under the angelic festival"), in Canto 30.65. The progressive unveiling of her beauties begins here (especially in $31.136-45$ ) to be established as a metaphor for revelation - to be pursued throughout the Paradiso. Her advent's supervening upon Virgil's disappearance, trailing funereal strains ("Manibus, oh, date lilia plenis" 21), from the scene shows love to be stronger than death in what is perhaps a yet more audacious troping of the meaning of a 
famous Virgilian text, that presaging Dido's doom ("Adnosco veteris vestigia flammae" translated in 30.48), even than those wrought by Statius. From out of a tradition of death and damnation rises poetry as revelatory of divine, immortal life.

These select examples indicate the way Dante concentrates on how poetry achieves a specifically religious transcendence, programmatically in the Statius episode and with undiminishing intensity through to the end of the cantica. The parallel endeavors of poetry and religion, of the disciplines of artistic refining and of spiritual-moral cleansing, become one and the same thing in the redemptive event of the Purgatorio. Moreover, the theme of poetry's redemptive power reflects specularly upon the redemption in act in Dante's poetry itself, giving it an ontological dimension, beyond the merely representational, as crucial to the project of the Commedia and to its "originality."

The Purgatorio shows quite emphatically the way in which the knowledge even of divine revelation is the effect of history. Centrally, the consciousness of Christian faith, which lies so much at the heart of the whole work, is analyzed in the Statius cantos in terms of pagan tradition as the historical ground on which the experience of conversion "rises" - the whole cantica being resurrectional in tenor and conception, verbally keyed to variegated inflections of "surto," starting from 1.7: "la morta poesì resurga" ("let dead poetry rise up"). Dante's creation of Statius recognizes the necessary continuity of Christian life with the life of the past deposited in tradition, but at the same time reveals its deeply mysterious coinciding with a new, "eternal" life which transcends the historical past altogether.

\section{Vanderbilt University}

\section{NOTES}

1 Luke's sense of the witness to the Resurrection of Jesus as based on the Church's always contemporary experience rather than exclusively on evidence conceming a past factum expresses itself again in his "latter treatise," the Acts of the Apostles. In recounting the choice by lot of Matthias to fill Judas Iscariot's place, Luke reports Peter's announcing that "Beginning from the baptism of John, unto that same day that he was taken up from us, must one be ordained to be a witness with us of his resurrection" (1.22). There would be no eye-witnesses in an empirical sense to choose from, but this is evidently not what is meant by "witness." The same inference is called for by the conflation in this passage of the resurrection with the whole of the gospel story.

2 Such information can be found, for example, in the commentary of Sapegno.

3 Perhaps Dante's simile does not say enough for us to be sure that he understood the significance of the Lukan pericope in just this way. Yet such a reading does come very close to the sort of understanding of history and its making, i.e. of its openness to the present of interpretation and to being remade through reading, that we are suggesting Dante momentously rediscovers, particularly here in his extraordinary interpretation of the biography of Statius. Dante's sense of history as an interpretive construction would have enabled him to understand intuitively and poetically this premise of the Lukan witness to the Resurrection regardless of whether he would have accepted it reflectively and 
dogmatically, whereas for us, given our modern, objectivist historical sense, the same point emerges only with what may seem rather subtle exegesis. In any case, however Dante understood Luke, the reaction of the present upon the historical past remains a crucial distinctive feature of Dante's poetic-interpretive practice.

4 Paratore summarizes critical opinion with regard to Statius' conversion as concurring that Dante made it up ("avrebbe favoleggiato per conto suo tutto"). Paratore emphasizes the contrast between the documentary biography in 21 and the apparently pure invention in 22: "Se in $\mathrm{Pg} \mathrm{XXI}$ abbiamo una precisa presentazione della figura e dell'opera di S[tazio], nel XXII troviamo invece sviluppato quel complesso di notizie che con la vera biografia di S[tazio] non han da fare né punto né poco, e che costituiscono il sorprendente di più introdotto da D[ante] . . ." (420). However, some possible evidence for an antecedent tradition of Statius' Christianity is discussed by Brugnoli.

5 So, for example, Montanari: "nel caso di Stazio, io credo, è bene sottintendere un tacito riferimento alla biografia di Dante: l'estesa descrizione di come Virgilio abbia elevato Stazio, e l'abbia salvato spiritualmente, io credo che si spieghi bene come chiara crittografia di cio che Virgilio ha operato nei riguardi di Dante: egli è stato maestro di poesia e di vita morale; lo ha avviato poi alla salvezza spirituale" (5). Recently, Scrivano reprises the point that "Stazio non è che una proiezione autobiografica di Dante" (196).

6 In a recent attempt to untie the classic knot, Balden claims to have found a satisfactory interpretation of the mis-citation of Virgil by Statius "Perchè non reggi tu, o sacra fame / de l'oro, l'appetito de' mortali?" that accounts for Virgil's silence and evident approval of Statius' use and understanding of his words: Priam's prodigality towards Polimnestor would be indirectly the cause of the latter's insatiable greed. From my point of view, the crux of the evident mistranslation is itself far more significant than any solution that normalizes it.

7 Note that to Statius, similarly, everything Virgil says is a sign of love: "Ogne tuo dir d'amor m'e caro cenno" (22.27).

8 This is the project particularly of Part 2.2.2 of Truth and Method.

9 See Cecchetti 109: "In the Commedia, the sun is a constant metaphor of God . . . ; here it signifies grace or an inspiration of Grace, and the "candele" have the sense of human teachings that can lead to the sun; but the disjunctive $o$ places the two sources of spiritual light on the same level, as far as their effective benefits are concemed."

10 According to Cecchetti, Statius is the only such figure in the poem.

11 In addition to Truth and Method 2.3.b, see Gadamer, "Das Alte und das Neue."

12 In a significant exception at the very end of the cantica (33.85-90), helping to maintain its balance, Beatrice reproves Dante's adherence to a "school" whose doctrine is as far from the divine way as is heaven from the earth, echoing the topos from Isaiah (55.9) of humiliation of all things human before God.

13 The topic has been skillfully pursued by Martinez.

$14 \mathrm{Cf}$. Scott; and Abrams.

15 A great merit of Barolini's Dante's Poets is the demonstration of Dante's "redemption" of his own love poetry in the Purgatorio. This is achieved through examination of the verbal microstructure of Inferno 2 and 5 in comparison with Purgatorio 2 and 23-26, specifically with regard to their stilnovistic inflections.

\section{WORKS CITED}

Abrams, Richard. "Illicit Pleasures: Dante Among the Sensualists (Purgalorio XXVI)." MLN 100 (1985): 1-41.

Alighieri, Dante. The Divine Commedy of Danle Alighieri. Purgatorio. Ed. Allen Mandelbaum. New York: Bantam, 1984. 
La Divina Commedia: Purgatorio. Ed. Natalino Sapegno. Firenze: La Nuova Italia,

1985.

Augustinus. De doctrina christiana libri quattuor. Ed. Guilelmus M. Green. Corpus Scriptorum Ecclesiasticorum. Vol. 80. Vindabonae: Hoelder-Pichler Tempsky, 1963.

Barolini, Teodolinda. Dante's Poets: Truth and Textuality in the Comedy. Princeton: Princeton UP, 1984.

Balden, Paolo. "Stazio e le possibili 'vere ragioni che son nascose' della sua conversione. Purgatorio XXII. 40-41." Lettere italiane 38 (April-June 1985): 149-65.

Brugnoli, Giorgio. "Statius Christianus." Italianistica 17 (1988): 9-15.

. "Lo Stazio di Dante e Benvenuto." Benvenuto da Imola lettore degli antichi e dei moderni. Atti del Convegno Internazionale, Imola, 26 e 27 maggio 1989. Ed. Pantaleo Palmieri and Carlo Paolazzi. Ravenna: Longo, 1991. 127-37.

Cecchetti, Giovanni. "The Statius Episode: Observations on Dante's Conception of Poetry." Lectura Dantis: A Forum for Dante Research and Interpretation 7 (1990): 96-114.

Freccero, John. Dante: The Poetics of Conversion. Ed. Rachel Jacoff. Cambridge: Harvard UP, 1986.

Gadamer, Hans-Georg . Truth and Method. Translation revised by Joel Weinsheimer and Donald G. Marshall. 2nd rev. ed. New York: Crossroad, 1989.

. "Das Alte und das Neue" (1981). Neure Philosophie II, Gesammelte Werke: Band

4. Tubingen: Mohr, 1987.

Heidegger, Martin. "The Origin of the Work of Art." Poetry, Language, Thought. Translations and Introduction by Albert Hofstadter. New York, Evanston, San Francisco, London: Harper \& Row Publishers, 1971. 15-87.

Holy Bible. Authorized King James Version, 1611. London: Oxford UP.

Kleinhenz, Christopher. "Virgil, Statius, and Dante: An Unusual Trinity." Lectura Dantis Newberryana 1 (1988): 37-55.

Martinez, R. L. "The Pilgrim's Answer to Bonagiunta and the Poetics of the Spirit." Stanford ltalian Review 3.1 (1983): 37-63.

Montanari, Fausto. "Il Canto XXII del Purgatorio." Lectura Dantis Romana. Torino: S.E.I., 1965. 3-21.

Nova Vulgata Bibliorum Sacrorum. Roma: Libreria Editrice Vaticana, 1979.

Paratore, Ettore. "Stazio." Enciclopedia Dantesca. 6 vols. Roma: Istituto dell'Enciclopedia Italiana, 1970-1976. 5.419-25.

Scoth, John. "Dante's dolce stil novo and the Vita Nuova." Italica 42 (1965): 98-107.

Scrivano, Riccardo. "Stazio personaggio, poeta e cristiano." Quaderni d' italianistica 13.2 (1992): 175-97.

Virgilius. Opera. Ed. Frederic Hirtzel. Oxford: Clarendon Press, 1942. 